ISBN 978-93-84468-94-1

International Conference on Education, Business and Management (ICEBM-2017)

Bali (Indonesia) Jan. 8-9, 2017

\title{
The Factors Influencing Turnover Intention among Employees: A Case Study on Pharmaceutical Company of Bangladesh
}

\author{
Samia Shabnaz, Rahat Sultana \\ Assistant Professor, Management Department, American International University- Bangladesh, email: \\ sayra27@yahoo.com \\ Student, Major in Human Resource, American International University- Bangladesh, email: \\ rahatsultana.gsa@gmail.com
}

\begin{abstract}
Pharmacentical industry is one of the leading industries that contribute to the economy of Bangladesh. Turnover among the employees is one of the biggest challenges for any organization and has been seen as a serious issue especially in the field of human resources management. This study explored the factors influencing turnover intention among existing skilled employees in Nuvista Pharma Limited. A total of 30 respondents were involved in this study. Several factors namely organizational factors, job stress, job security, promotion opportunities, pay level and rewards, quality of work life and job satisfaction were examined to determine their relationship with turnover intention. Data was obtained and has been analyzed using Statistical Package for Social Sciences (SPSS) version 20. The study findings revealed a number of demographic characteristics like gender, educational qualification and experience have diverse impact on the factors like organizational element, job stress, job security, promotion opportunities, pay level, rewards, quality of work life and job satisfaction which influence the turnover intention of the employees. As the turnover intention is all about a thinking process that can create dissatisfaction, the pharmaceutical companies need to concentrate on these issues to promote organizational commitment and loyalty of the employees. This study will help the organizations to design human resource management policy to satisfy the expectation of different group of employees which will reduce the turnover intention of the employees.
\end{abstract}

Keywords: Turnover Intention, Pharmaceutical Company, Organizational Factors

\section{Introduction}

The pharmaceutical industries are currently contributing significantly in the economy of Bangladesh. After the Ordinance in 1982 the scenario of pharmaceutical industries changed considerably.[1] About 240 pharmaceutical companies are now operating in the country, which are manufacturing about 5,600 brands of medicines in different dosage forms. According to a report of the International Management System (IMS) published in June 2015, the size of the pharmaceutical market of Bangladesh is estimated to be approximate 117 billion taka, with an annual growth rate of about $11.37 \%$ [2]. Bangladesh pharmaceutical industries are the largest white-collar employment sector of the country, which are employing around 115,000 workers [3].

As the competition of the business world have increased, it is becoming essential for organizations to manage employee turnover. According to Grobleret al. (2006) a certain amount of turnover is expected, unavoidable and considered beneficial to the organization but excessive turnover creates an unstable workforce and increases human resources (HR) cost.[4] Losing a single key worker can decrease the likelihood of a project's success and can reduce investors' confidence in the firm [5]. There are a number of organizational factors including types of industry, types of occupation, size of organization, payment, supervisory levels, locations, selection processes, work environment, work assignments, benefits, and promotions affects turnover 
[6][7]. As most of the owners of the business organizations have lack of awareness about the importance of the turnover issue, very few researches have been conducted in Bangladesh in this regard. The study intended to assess the factors influencing turnover intention of employees in the pharmaceutical company of Bangladesh. The rest of this paper is organized with a brief literature review on the factors influencing turnover intention, the research methodology and the results of data based on the case study. Finally the paper concluded with major finding and indicated some future research directions.

\section{Review of Related Literature}

For a business manager, staff turnover is one key area to monitor throughout the year. [8] When an employee leaves an organization, it can have a variety of effects on the organization as well as the individual employee and the society [7]. Durbin, (2000) portrays that employee's turnover is not only costly both to individual organizations and the economy as a whole but also affects moral, profitability, efficiency and productivity as well.[9] A large number of scholars have determined that intent to stay or leave is strongly and consistently related to voluntary turnover [10][11]. The researchers basically concentrate to research on employee turnover intention due to the data of employees who leaving voluntarily is difficult to collect [12] [13]. A number of studies have been done related to intent to leave or turnover [14] [15]. Firth et al. (2003) defined that managers can reduce employee turnover rate by reduce employee turnover intention, and then managers need to regulate the relationships between supervisors and subordinates in order to reduce stress from management. [16]

Various factors or reasons responsible for employees' turnover were identified by a number of theoretical and empirical literatures. Suleiman Al Battat and Mat Som [17] revealed that turnover intention is the crucial stage before the actual turnover occurs. Unmet expectations can lead to turnover intentions which force the employee to ultimately quit. Demographic variables like age, tenure and income level were discovered to be negatively associated with turnover intention [18][19][20][21] [22], level of education is positively related to turnover as employees with higher education levels have higher tendency to quit [23][19]. With regard to job category, Tai and Robinson (1998) [22] and Price and Mueller (1986) [21] found that non-managerial employees have higher tendency to quit than managerial employees. Arnold, H. J., and Feldman, D. C. (1982) indicated the Factors that usually impact turnover rate are age, tenure, job satisfaction and person-organization fit. [18]. Armstrong (2011) argues that the prospect of getting higher pay elsewhere is one of the most obvious contributions to turnover. [24] Moreover, other studies have confirmed that salary level has a significantly positive effect on turnover intention [25] [26]. Somers (2009) claimed that stressful work environments can lead to serious physical and emotional detrimental effects on employees. [27] The intention of turnover has been accelerating with the increasing job insecurity sense [28]. Perceived career opportunities outside the organization and lack of career advancement opportunities inside organization increase the employee's intentions to leave the organization [29]. Job satisfaction and turnover intention has native correlation whereby job satisfaction, strongly influence the turnover of employees [30]. Han and Jekel, (2011) mentioned that employees who are not satisfied with their jobs will experience negative attitudes towards their jobs and positive attitudes towards the intention to quit the job.[31] Employee also pushed to leave job due to the dissatisfaction in their present workplace [32]. Eisenberger et. al (1990), suggested that an employee's view regarding organization is strongly concerned to their relationship with supervisor.[33] If supervisor support, open communication and have good relationship with employees, the employees turnover intention are likely less and more engaged with organization [34]. A poor relationship with the management can be an important reason for the employees to leave their jobs. It is relatively rare for people to leave jobs in which they are happy even offered by higher salary elsewhere. [35] 


\section{Methodology}

The research begins by analyzing the factors that influence turnover intention through literature review. It was through a case study approach on Nuvista Pharma Limited. The data collected was analyzed by using SPSS version 20. The simple random sampling technique was used to select respondents from the various departments in the organization. The target population chosen by the researcher for this study was made up of management and both the senior and junior staff of Nuvista Pharma Limited. Primary data for the study were gathered by using questionnaires which were administered to the targeted respondents. There were 30 respondents and crosstab, frequency count, percentage were used to generate tables and graphs. The questionnaire had two sections containing demographic and the factors in relation to the respondent's intention to leave the organization. Meanwhile, the questionnaires were developed using a five-point Likert scale.

\section{Analysis and Results}

\subsection{Reliability Test}

The Cronbach Alpha testing was used as it is the most well accepted reliability test tools applied by social researcher [36]. A Cronbach measure indicates that if the reliability is more than 0.8 than it is considered to be good which is also noticeable in Table -1 .

TABLE I: Reliability Statistics

\begin{tabular}{|c|c|}
\hline CRONBACH'S ALPHA & N OF ITEMS \\
\hline .803 & 18 \\
\hline
\end{tabular}

\subsection{Demographic Information:}

From the table 2 it has been observed that the pharmaceutical company is dominated by male employees $(73 \%)$ and significant number of employees $(76.7 \%)$ have post-graduation degree which indicates that the industry consists of high skilled people. Almost half of the employees (46.7\%) belong to the age group of 26-30 and substantial number of employees $(43.3 \%)$ has more than 5 years of work experience in current organization.

TABLE II: Demographic Profile

\begin{tabular}{|c|c|c|c|c|c|}
\hline & & FREQUENCY & PERCENT & VALID PERCENT & CUMULATIVE PERCENT \\
\hline GENDER & MALE & 22 & 73.3 & 73.3 & 13.3 \\
\hline & FEMALE & 8 & 26.7 & 26.7 & 100.0 \\
\hline EDUCATION & TOTAL & 30 & 100.0 & 100.0 & 20.0 \\
\hline & GRADUATION & 6 & 20.0 & 20.0 & 96.7 \\
\hline & POST-GRADUATION & 23 & 76.7 & 76.7 & 100.0 \\
\hline & OTHERS & 1 & 3.3 & 3.3 & 10.0 \\
\hline & TOTAL & 30 & 100.0 & 100.0 & 56.7 \\
\hline & $20-25$ & 3 & 10.0 & 10.0 & 86.7 \\
\hline & $26-30$ & 14 & 46.7 & 46.7 & 100.0 \\
\hline & 30-40 & 9 & 30.0 & 30.0 & 13.3 \\
\hline & MORE THAN 40 & 4 & 13.3 & 100.0 & 20.0 \\
\hline & TOTAL & 30 & 100.0 & 20.0 & 53.3 \\
\hline & LESS THAN 1 YEAR & 6 & 20.0 & 33.3 & 56.7 \\
\hline & $1-3$ YEARS & 10 & 33.3 & 3.3 & 100.0 \\
\hline
\end{tabular}

\subsection{Gender:}

The factors influence turnover intention varies based on gender, educational qualification and experience. According to gender, table 3 shows that female employees are more (37.5\%) believing that the job stresses influences the turnover intention. The significance of the relation is also visible in the chi square test $\left(\mathrm{X}^{\wedge} 2=9.996\right.$, 
$\mathrm{df}=4, \mathrm{p}=0.040)$. Table 4 indicates that a significant number of female employees $(37.5 \%)$ are strongly agreeing that lack of supervisor's support influences the turnover intention. The significance of the relation is also visible in the chi square test $\left(\mathrm{X}^{\wedge} 2=10.335, \mathrm{df}=3, \mathrm{p}=0.016\right)$.

\begin{tabular}{|c|c|c|c|c|c|c|c|c|}
\hline \multicolumn{9}{|c|}{ TABLE III: Job Stress Can Influence The Employee to Leave The Organization } \\
\hline & & & $\begin{array}{l}\text { STRONGLY } \\
\text { DISAGREE }\end{array}$ & DISAGREE & NEUTRAL & AGREE & STRONGLY AGREE & TOTAL \\
\hline \multirow{4}{*}{ GENDER } & \multirow{2}{*}{ MALE } & COUNT & 0 & 3 & 5 & 13 & 1 & 22 \\
\hline & & $\%$ WITHIN GENDER & $0.0 \%$ & $13.6 \%$ & $22.7 \%$ & $59.1 \%$ & $4.5 \%$ & $100.0 \%$ \\
\hline & \multirow{2}{*}{ FEMALE } & COUNT & 1 & 0 & 2 & 2 & 3 & 8 \\
\hline & & $\%$ WITHIN GENDER & $12.5 \%$ & $0.0 \%$ & $25.0 \%$ & $25.0 \%$ & $37.5 \%$ & $100.0 \%$ \\
\hline \multirow{2}{*}{\multicolumn{2}{|c|}{ TOTAL }} & COUNT & 1 & 3 & 7 & 15 & 4 & 30 \\
\hline & & $\%$ WITHIN GENDER & $3.3 \%$ & $10.0 \%$ & $23.3 \%$ & $50.0 \%$ & $13.3 \%$ & $100.0 \%$ \\
\hline
\end{tabular}

\begin{tabular}{|c|c|c|c|c|c|c|c|}
\hline \multicolumn{8}{|c|}{ TABLE IV: Lack of Supervisor's Support Can Influence The Employee to Leave The Organization } \\
\hline & & & DISAGREE & NEUTRAL & AGREE & STRONGLY AGREE & TOTAL \\
\hline \multirow{4}{*}{ GENDER } & \multirow{2}{*}{ MALE } & COUNT & 1 & 7 & 14 & 0 & 22 \\
\hline & & $\%$ WITHIN GENDER & $4.5 \%$ & $31.8 \%$ & $63.6 \%$ & $0.0 \%$ & $100.0 \%$ \\
\hline & \multirow{2}{*}{ FEMALE } & COUNT & 1 & 1 & 3 & 3 & 8 \\
\hline & & $\%$ WITHIN GENDER & $12.5 \%$ & $12.5 \%$ & $37.5 \%$ & $37.5 \%$ & $100.0 \%$ \\
\hline \multirow{2}{*}{\multicolumn{2}{|c|}{ TOTAL }} & COUNT & 2 & 8 & 17 & 3 & 30 \\
\hline & & $\%$ WITHIN GENDER & $6.7 \%$ & $26.7 \%$ & $56.7 \%$ & $10.0 \%$ & $100.0 \%$ \\
\hline
\end{tabular}

\subsection{Educational Qualification}

Based on educational qualification the importance of the factors that influence turnover intention differs. Table 5 portrays that a substantial number of post graduate employees (86.9\%) are emphasizing the organizational elements that influences the turnover intention whereas only $50 \%$ of the graduates agreed on this issue. The significance of the relation is also visible in the chi square test $\left(X^{\wedge} 2=17.655, \mathrm{df}=6, \mathrm{p}=0.007\right)$.

\begin{tabular}{|c|c|c|c|c|c|c|c|}
\hline \multicolumn{8}{|c|}{ TABLE V: Organizational elements Influencing The Employees to Leave The Organization } \\
\hline & & & DISAGREE & NEUTRAL & AGREE & STRONGLY AGREE & TOTAL \\
\hline \multirow{6}{*}{ EDUCATION LEVEL } & \multirow{2}{*}{ GRADUATION } & COUNT & 0 & 3 & 1 & 2 & 6 \\
\hline & & $\%$ WITHIN EDUCATION LEVEL & $0.0 \%$ & $50.0 \%$ & $16.7 \%$ & $33.3 \%$ & $100.0 \%$ \\
\hline & \multirow{2}{*}{$\begin{array}{c}\text { POST- } \\
\text { GRADUATION }\end{array}$} & COUNT & 3 & 0 & 11 & 9 & 23 \\
\hline & & $\%$ WITHIN EDUCATION LEVEL & $13.0 \%$ & $0.0 \%$ & $47.8 \%$ & $39.1 \%$ & $100.0 \%$ \\
\hline & \multirow{2}{*}{ OTHERS } & COUNT & 0 & 1 & 0 & 0 & 1 \\
\hline & & $\%$ WITHIN EDUCATION LEVEL & $0.0 \%$ & $100.0 \%$ & $0.0 \%$ & $0.0 \%$ & $100.0 \%$ \\
\hline \multirow{2}{*}{\multicolumn{2}{|c|}{ TOTAL }} & COUNT & 3 & 4 & 12 & 11 & 30 \\
\hline & & $\%$ WITHIN EDUCATION LEVEL & $10.0 \%$ & $13.3 \%$ & $40.0 \%$ & $36.7 \%$ & $100.0 \%$ \\
\hline
\end{tabular}

\begin{tabular}{|c|c|c|c|c|c|c|c|c|}
\hline \multicolumn{9}{|c|}{ TABLE VI: Job Security Can Influence The Employee to Leave The Organization } \\
\hline & & & $\begin{array}{l}\text { STRONGLY } \\
\text { DISAGREE }\end{array}$ & DISAGREE & NEUTRAL & AGREE & $\begin{array}{c}\text { STRONGLY } \\
\text { AGREE }\end{array}$ & TOTAL \\
\hline \multirow{6}{*}{$\begin{array}{l}\text { EDUCATION } \\
\text { LEVEL }\end{array}$} & \multirow{2}{*}{ GRADUATION } & COUNT & 1 & 0 & 2 & 2 & 1 & 6 \\
\hline & & \% WITHIN EDUCATION LEVEL & $16.7 \%$ & $0.0 \%$ & $33.3 \%$ & $33.3 \%$ & $16.7 \%$ & $100.0 \%$ \\
\hline & \multirow{2}{*}{$\begin{array}{c}\text { POST- } \\
\text { GRADUATION }\end{array}$} & COUNT & 0 & 2 & 2 & 14 & 5 & 23 \\
\hline & & $\%$ WITHIN EDUCATION LEVEL & $0.0 \%$ & $8.7 \%$ & $8.7 \%$ & $60.9 \%$ & $21.7 \%$ & $100.0 \%$ \\
\hline & \multirow{2}{*}{ OTHERS } & COUNT & 0 & 1 & 0 & 0 & 0 & 1 \\
\hline & & $\%$ WITHIN EDUCATION LEVEL & $0.0 \%$ & $100.0 \%$ & $0.0 \%$ & $0.0 \%$ & $0.0 \%$ & $100.0 \%$ \\
\hline \multirow{2}{*}{\multicolumn{2}{|c|}{ TOTAL }} & COUNT & 1 & 3 & 4 & 16 & 6 & 30 \\
\hline & & $\%$ WITHIN EDUCATION LEVEL & $3.3 \%$ & $10.0 \%$ & $13.3 \%$ & $53.3 \%$ & $20.0 \%$ & $100.0 \%$ \\
\hline
\end{tabular}

\begin{tabular}{|c|c|c|c|c|c|c|c|c|}
\hline \multicolumn{9}{|c|}{ TABLE VII: Career Growth Can Influence The Employee to Leave The Organization } \\
\hline & & & $\begin{array}{l}\text { STRONGLY } \\
\text { DISAGREE }\end{array}$ & DISAGREE & NEUTRAL & AGREE & $\begin{array}{c}\text { STRONGLY } \\
\text { AGREE }\end{array}$ & TOTAL \\
\hline \multirow{6}{*}{$\begin{array}{l}\text { EDUCATION } \\
\text { LEVEL }\end{array}$} & \multirow{2}{*}{ GRADUATION } & COUNT & 1 & 0 & 2 & 1 & 2 & 6 \\
\hline & & $\%$ WITHIN EDUCATION LEVEL & $16.7 \%$ & $0.0 \%$ & $33.3 \%$ & $16.7 \%$ & $33.3 \%$ & $100.0 \%$ \\
\hline & \multirow{2}{*}{$\begin{array}{c}\text { POST- } \\
\text { GRADUATION } \\
\end{array}$} & COUNT & 1 & 0 & 2 & 13 & 7 & 23 \\
\hline & & $\%$ WITHIN EDUCATION LEVEL & $4.3 \%$ & $0.0 \%$ & $8.7 \%$ & $56.5 \%$ & $30.4 \%$ & $100.0 \%$ \\
\hline & \multirow{2}{*}{ OTHERS } & COUNT & 0 & 1 & 0 & 0 & 0 & 1 \\
\hline & & $\%$ WITHIN EDUCATION LEVEL & $0.0 \%$ & $100.0 \%$ & $0.0 \%$ & $0.0 \%$ & $0.0 \%$ & $100.0 \%$ \\
\hline \multirow{2}{*}{\multicolumn{2}{|c|}{ TOTAL }} & COUNT & 2 & 1 & 4 & 14 & 9 & 30 \\
\hline & & $\%$ WITHIN EDUCATION LEVEL & $6.7 \%$ & $3.3 \%$ & $13.3 \%$ & $46.7 \%$ & $30.0 \%$ & $100.0 \%$ \\
\hline
\end{tabular}


From Table 6 it can be assumed that a considerable number of post graduate employees (82.6\%) are stressing the job security as a stimulus for turnover intention however $50 \%$ graduates emphasized in this regard. The significance of the relation is also visible in the chi square test $\left(X^{\wedge} 2=16.540, d f=8, p=0.035\right)$.

Table 7 indicates that lack of career growth opportunity in an important factor which can affect the turnover intention of the employees with post-graduation degree as most of them agreed (86.9\%) compared to graduates $(50 \%)$. The significance of the relation is also visible in the chi square test $\left(\mathrm{X}^{\wedge} 2=34.883, \mathrm{df}=8, \mathrm{p}=0.000\right)$.

\subsection{Age}

Demographic factor age also influence turnover intention. Table 8 portrays that a substantial number of people from age group 26-30 and 30-40 are influenced by the organizational factor for their turnover intention whereas it is less for the age group 20-25 and above 40. The significance of the relation is also visible in the chi square test $\left(\mathrm{X}^{\wedge} 2=19.278, \mathrm{df}=9, \mathrm{p}=0.023\right)$.

\begin{tabular}{|c|c|c|c|c|c|c|c|}
\hline \multicolumn{8}{|c|}{ TABLE VIII: Organizational elements Influencing The Employees to Leave The Organization } \\
\hline & & & DISAGREE & NEUTRAL & AGREE & STRONGLY AGREE & TOTAL \\
\hline \multirow{8}{*}{ AGE } & \multirow{2}{*}{$20-25$} & COUNT & 0 & 2 & 0 & 1 & 3 \\
\hline & & $\%$ WITHIN AGE & $0.0 \%$ & $66.7 \%$ & $0.0 \%$ & $33.3 \%$ & $100.0 \%$ \\
\hline & \multirow{2}{*}{$26-30$} & COUNT & 1 & 2 & 5 & 6 & 14 \\
\hline & & $\%$ WITHIN AGE & $7.1 \%$ & $14.3 \%$ & $35.7 \%$ & $42.9 \%$ & $100.0 \%$ \\
\hline & \multirow{2}{*}{$30-40$} & COUNT & 0 & 0 & 6 & 3 & 9 \\
\hline & & $\%$ WITHIN AGE & $0.0 \%$ & $0.0 \%$ & $66.7 \%$ & $33.3 \%$ & $100.0 \%$ \\
\hline & \multirow{2}{*}{ MORE THAN 40} & COUNT & 2 & 0 & 1 & 1 & 4 \\
\hline & & $\%$ WITHIN AGE & $50.0 \%$ & $0.0 \%$ & $25.0 \%$ & $25.0 \%$ & $100.0 \%$ \\
\hline \multirow{2}{*}{\multicolumn{2}{|c|}{ TOTAL }} & COUNT & 3 & 4 & 12 & 11 & 30 \\
\hline & & $\%$ WITHIN AGE & $10.0 \%$ & $13.3 \%$ & $40.0 \%$ & $36.7 \%$ & $100.0 \%$ \\
\hline
\end{tabular}

TABLE IX: Employee Benefits( Bonuses, Other Benefits) Can Influence The Employee to Leave The Organization

\begin{tabular}{|c|c|c|c|c|c|c|c|c|}
\hline & & & STRONGLY DISAGREE & DISAGREE & NEUTRAL & AGREE & STRONGLY AGREE & TOTAL \\
\hline \multirow[t]{8}{*}{ AGE } & \multirow[t]{2}{*}{$20-25$} & COUNT & 1 & 1 & 0 & 0 & 1 & 3 \\
\hline & & $\%$ WITHIN AGE & $33.3 \%$ & $33.3 \%$ & $.0 \%$ & $.0 \%$ & $33.3 \%$ & $100.0 \%$ \\
\hline & \multirow[t]{2}{*}{$26-30$} & CounT & 0 & 2 & 2 & 4 & 6 & 14 \\
\hline & & $\%$ WITHIN AGE & $.0 \%$ & $14.3 \%$ & $14.3 \%$ & $28.6 \%$ & $42.9 \%$ & $100.0 \%$ \\
\hline & \multirow[t]{2}{*}{$30-40$} & COUNT & 0 & 0 & 0 & 8 & 1 & 9 \\
\hline & & $\%$ WITHIN AGE & $.0 \%$ & $.0 \%$ & $.0 \%$ & $88.9 \%$ & $11.1 \%$ & $100.0 \%$ \\
\hline & \multirow[t]{2}{*}{ MORE THAN 40} & COUNT & 0 & 0 & 1 & 2 & 1 & 4 \\
\hline & & $\%$ WITHIN AGE & $.0 \%$ & $.0 \%$ & $25.0 \%$ & $50.0 \%$ & $25.0 \%$ & $100.0 \%$ \\
\hline \multirow{2}{*}{\multicolumn{2}{|c|}{ TOTAL }} & CounT & 1 & 3 & 3 & 14 & 9 & 30 \\
\hline & & $\%$ WITHIN AGE & $3.3 \%$ & $10.0 \%$ & $10.0 \%$ & $46.7 \%$ & $30.0 \%$ & $100.0 \%$ \\
\hline
\end{tabular}

\begin{tabular}{|c|c|c|c|c|c|c|c|c|}
\hline \multicolumn{9}{|c|}{ TABLE X: Job Satisfaction Can Influence The Employee to Leave The Organization } \\
\hline & & & STRONGLY DISAGREE & DISAGREE & NEUTRAL & AGREE & STRONGLY AGREE & TOTAL \\
\hline \multirow[t]{8}{*}{ AGE } & \multirow[t]{2}{*}{$20-25$} & COUNT & 1 & 0 & 0 & 0 & 2 & 3 \\
\hline & & $\%$ wITHIN AGE & $33.3 \%$ & $.0 \%$ & $.0 \%$ & $.0 \%$ & $66.7 \%$ & $100.0 \%$ \\
\hline & \multirow[t]{2}{*}{$26-30$} & COUNT & 1 & 0 & 2 & 3 & 8 & 14 \\
\hline & & $\%$ WITHIN AGE & $7.1 \%$ & $.0 \%$ & $14.3 \%$ & $21.4 \%$ & $57.1 \%$ & $100.0 \%$ \\
\hline & \multirow[t]{2}{*}{$30-40$} & COUNT & 0 & 0 & 0 & 7 & 2 & 9 \\
\hline & & $\%$ WITHIN AGE & $.0 \%$ & $.0 \%$ & $.0 \%$ & $77.8 \%$ & $22.2 \%$ & $100.0 \%$ \\
\hline & \multirow[t]{2}{*}{ MoRE THAN 40} & COUNT & 0 & 1 & 0 & 3 & 0 & 4 \\
\hline & & $\%$ WITHIN AGE & $.0 \%$ & $25.0 \%$ & $.0 \%$ & $75.0 \%$ & $.0 \%$ & $100.0 \%$ \\
\hline & \multirow[t]{2}{*}{ TOTAL } & COUNT & 2 & 1 & 2 & 13 & 12 & 30 \\
\hline & & $\%$ wITHIN AGE & $6.7 \%$ & $3.3 \%$ & $6.7 \%$ & $43.3 \%$ & $40.0 \%$ & $100.0 \%$ \\
\hline
\end{tabular}

Based on age the employees benefit can have diverse type of influence on turnover intention. Table 9 indicated the young employees age from $20-25$ are not influenced by benefit. On the other hand a substantial number of employees' turnover intention is affected by the benefits for the age group from 26 to 40 above. The 
significance of the relation is also visible in the chi square test $\left(X^{\wedge} 2=22.264, d f=12, p=0.035\right)$. Table 10 specifies that age also influence the satisfaction level of employees which ultimately impact on turnover intention. For the age group 26 and above the satisfaction is a major factor that influence turnover intention but it is less emphasized by the age group 20-25. The significance of the relation is also visible in the chi square test $\left(\mathrm{X}^{\wedge} 2=22.970, \mathrm{df}=12, \mathrm{p}=0.028\right)$.

\section{Conclusions}

The study findings revealed a number of demographic characteristics like gender, educational qualification and experience have diverse impact on the factors like organizational elements, job stress, job security, promotion opportunities, pay level, rewards, quality of work life and job satisfaction which influence the turnover intention of the employees. The intention of female employees to leave the job is more related to job stress and supervisor's support. Moreover the post graduate employees emphasized more on the factors like organizational factors, job security and career growth opportunity for their turnover intention. The older employees' turnover intentions are influenced more by organizational factors, employee benefits and job satisfaction whereas it has less effect on younger employees. As the turnover intention is all about a thinking process that can create dissatisfaction the pharmaceutical companies need to concentrate on these issues to promote organizational commitment, and loyalty of the employees. This study will help the organizations to design human resource management policy to satisfy the expectation of different group which will reduce the turnover intention of the employees. The research concentrated only on the pharmaceutical companies. Since the impact of the factors varies based on industry, further in-depth studies can be performed in different industries.

\section{Reference}

[1] Reich, M.R., "Bangladesh pharmaceutical policy and politics," Health Policy Plan 9, 130-143, 1994

[2] Hossain, M.M. and Shoaib, S.M., "Role of pharmaceutical sector in the national economy of Bangladesh W. J. Pharm,” Pharmaceut. Sci. 3, 951-960, 2014

[3] EBL Securities Limited (EBL), Pharmaceutical Sector Overview, Dhaka, 2015

[4] Grobler, P.A., S. Warnich, M.R. Carrel, N.F. Elbert and R.D. Hatfield, Human resource management in South Africa, London: Thompson, 2006.

[5] Control Turnover by Understanding its Causes, Handbook of Principles of Organizational Behavior. Malden, Lee, T. And Mitchell, T. , MA: Blackwell Publishers Ltd, 2000 p. 90-104.

[6] Arthur, M. B., \& Rousseau, D. M. The boundary less career: A new employment principle for a new organizational era. New York, NY: Oxford University Press, 2001.

[7] Mobley, W. H., Employee turnover: Causes, consequences, and control, Philippines: Addison-Wesley Publishing, 1982.

[8] Kreitner, R. and A.J. Kinicki, Organizational Behaviour, 7th Ed., New York: Irwin McGraw Hill, 2007

[9] Durbin, H., Applying psychology: Individual and organizational, London, England: Prentice Hall, 2000

[10] Wright,T.A. and Bonett, D.G., "Job satisfaction and psychological well-being as non additive predictors of workplace turnover", Journal of Management, 33(2), 141-60. 2007

[11] Mathieu, J. E. and Zajac, D. M., "A review and meta-analysis of the antecedents, correlates, and consequences of organizational commitment," Psychological Bulletin, 108(2), 171-194, 1990

[12] Currivan, D.B., "The causal order of job satisfaction and organizational commitment in models of employee turnover," Human Resource Management Review, 9(4), 495-524. 2000

[13] Handbook of Organizational Measurement, Price, J.L., MCB University Press, Bradford, 1997.

[14] Lee, C.H. and Bruvold, N.T., "Creating value for employees: investment in employee development," International Journal of Human Resource Management, 14(6), 981-1000, 2003. 
[15] Koch, J. and Steers, R., "Job attachment satisfaction, and turnover among public sector employees," Journal of Vocational Behavior, 12(1), 119-128, 1978.

[16] Firth, L., Mellor, D.J., Moore, K.A. and Loquet, C., "How can managers reduce employee intention to quit?," Journal of Managerial Psychology, 19(2), 170-87, 2004.

[17] Suleiman Al Battat, A., and Mat Som, A. , "Employee Dissatisfaction and Turnover Crises in the Malaysian Hospitality Industry,” International Journal of Business \& Management, 8(5), 62-71, 2013.

[18] Arnold, H. J., \& Feldman, D. C., "A multivariate analysis of the determinants of job turnover," Journal of Applied Psychology, 67(3), 350-360, 1982

[19] Cotton, J. L., \& Tuttle, J. M., "Employee turnover: A meta-analysis and review with implications for research," Academy of Management Review, 11(1), 55-70, 1986

[20] Gerhart, B., "Voluntary turnover and alternative job opportunities", Journal of Applied Psychology, 75(5), 467-476, 1990.

[21] Price, J. L., \& Mueller, C. W., Absenteeism and turnover of hospital employees. JAI Press. 1986.

[22] Tai, T. W. C., \& Robinson, C. D., "Reducing staff turnover: A case study of dialysis facilities," Health Care Management Review, 23(4), 21-42, 1998

[23] Berg, T. R., "The importance of equity perception and job satisfaction in predicting employee intent to stay at television stations," Group \& Organization Management, 16(3), 268-284, 1991.

[24] Handbook of human resource management practices, $12^{\text {th }}$ ed., Armstrong, M., New York: Prentice-Hall, 2011.

[25] Ghiselli, R.F., J.M. La Lopa and B. Bai, "Job Satisfaction, Life Satisfaction, and Turnover Intent: Among Foodservice Managers," Cornell Hotel and Restaurant Administration Quarterly Vol.42, No.2, pp. 28-37. 2001

[26] Summers, T.P and W.H. Hendrix, "Modeling the Role of Pay Equity Perceptions: A Field Study," Journal of Occupational Psychology, Vol.64, No.1, pp.145-157, 1991.

[27] Somers, M.J., "The combined influence of affective, continuance and normative commitment on employee withdrawal," Journal of Vocational Behaviour, 74(1), 75-81, 2009.

[28] Tett RP, Meyer JP , "Job Satisfaction, Organizational Commitment, Turnover Intention, and Turnover: Path Analyses Based on Meta-analytic Findings", Pers. Psychol. 46:259-293. 1993

[29] Stahl, G.K., Chua, C.H., Caligiuri, P., Cerdin, J.L.E., \& Taniguchi, M., "Predictors Of turnover intentions in learning-driven and demand-driven international assignments: The role of repatriation concerns, satisfaction with company support, and perceived career advancement opportunities," Human Resource Management, 48(1), 91-111, 2009

[30] Ahmad, B., Shahid, M., Zill-E-, H., and Haider, S., "Turnover Intention: An HRM Issue in Textile Sector," Interdisciplinary Journal of Contemporary Research in Business, 3(12), 125-130, 2012

[31] Han, G., \& Jekel, M., "The mediating role of job satisfaction between leader-member exchange and turnover intentions," Journal Of Nursing Management, 19(1), 41-49, 2011

[32] Shamsuzzoha, and Shumon, "Employee Turnover-a Study of its Causes and Effects to Different Industries in Bangladesh,” International Journal of Humanities and Social Science, Special Issue - July 2012.

[33] Eisenberger, R., Fasolo, P., and Davis-LaMastro, V., "Perceived organizational support and employee diligence, commitment, and innovation," Journal of Applied Psychology, 75(1), 51-59, 1990

[34] Greenhaus, J.H. \& Callanan, G.A., Career Management. The Dryden Press, Fort Worth, Texas, 1994.

[35] Carsten, J.M. And Spector, P.E., "Unemployment, Job Satisfaction, and Employee Turnover: A Meta-Analytic Test of the achesney Model," Journal of Applied Psychology, 72: 374-381, 1987.

[36] Sekaran, U., Research methods for business: A skill-building approach. United Kingdom: Wiley \& Sons Ltd., 2003 